\title{
Evaluasi Usabilitas Layanan Sistem Informasi Akademik Berdasarkan Kombinasi ServQual dan Webqual Studi Kasus : SIAKAD Politeknik XYZ

\author{
Agus Hermanto ${ }^{1)}$, Supangat ${ }^{2)}$, Fridy Mandita ${ }^{3)}$ \\ ${ }^{1,2,3)}$ Teknik Informatika, Fakultas Teknik, Universitas 17 Agustus 1945 \\ Jl. Semolowaru 45, Surabaya 60118 \\ ${ }^{1)}$ hermanto_if@untag-sby.ac.id \\ ${ }^{2)}$ supangat@untag-sby.ac.id \\ ${ }^{3)}$ fridymandita@untag-sby.ac.id
}

\begin{abstract}
Abstrak - Layanan sistem informasi akademik yang sudah digunakan beberapa tahun terakhir, pada dasarnya bertujuan untuk memberikan dukungan terpenuhinya kebutuhan proses akademik di kampus. Namun, seiring dengan berjalannya waktu, diperlukan evaluasi agar efektivitas dari penggunaan sistem tersebut dapat diketahui, sehingga sistem informasi akademik tersebut dapat terus dikembangkan atau ditingkatkan. Selama ini dalam mengembangkan layanan sistem informasi berbasis web kurang memperhatikan faktor usabilitas dari pengguna, padahal pengembangan website yang berkualitas membutuhkan desain kegunaan dan evaluasi dari keterpaduan interaksi manusia dan komputer, aspek kognitif, teknik psikologi dan perangkat lunak. Dalam penelitian ini, untuk mengukur kualitas layanan berbasis web menggunakan kombinasi metode ServQual dan WebQual dan dianalisis menggunakan SEM, yang secara efektif untuk menangani multikolinieritas (jika banyak variabel yang sangat berkorelasi), karena membuatnya lebih kuat dari faktor analisis dan regresi berganda dalam evaluasi usabilitas. Hasil pengukuran menggunakan SEM menunjukkan bahwa jika variabel subyektif (ServQual) dari indeks usabilitas ditingkatkan, maka variabel obyektif dari indeks usabilitas (WebQual) juga akan meningkat secara signifikan. Hasil penelitian ini menunjukkan bahwa aspek-aspek obyektif dan subjektif yang menjadi faktor penilaian usabilitas mendapatkan hasil yang baik dan memuaskan dari hampir semua responden dalam menggunakan layanan sistem informasi akademik kampus XYZ.
\end{abstract}

Kata Kunci-Sistem Informasi, Structural Equation Modelling (SEM), Usabilitas, WebQual, ServQual

Abstract - The Services of academic information systems already used last few years. Basically, its aim to support the fulfillment of the academic process on campus. However, over time, is needed in order to evaluate the effectiveness of the use of such systems can be known so that academic information system that can be developed or improved. During this time in developing a web-based information system services less attention on the reusability of the user, whereas the development of quality website design requires the use and evaluation of the integration of human and computer interaction, cognitive, psychological and software engineering. In this study, to measure the quality of web-based services using a combination of methods ServQual and WebQual and analyzed using SEM, which is effective to handle multicollinearity (if a lot of variables that are highly correlated), because it makes it more powerful than the factor analysis and regression in the evaluation usability. The measurement results using SEM showed that if a subjective variable (ServQual) on enhanced usability index, then the objective of the index variable reusability (WebQual) will also be increased significantly. The results of this study indicate that aspects of the objective and the subjective factor in the assessment of reusability get good results and satisfying of almost all respondents in using academic information system.

Keywords-Structural Equation Modelling (SEM), Usability, WebQual, ServQual

Article history:

Received 18 February 2017; Received in revised form 23 March 2017; Accepted 30 March 2017; Available online 28 April 2017

\section{PENDAhUluan}

Sistem informasi akademik berbasis web merupakan salah satu tool yang sangat dibutuhkan dalam menunjang kegiatan akademik di kampus. Ketika proses implementasi suatu sistem telah selesai, maka tahapan berikutnya adalah melakukan proses evaluasi, sehingga dapat diketahui tingkat keberhasilan proses implementasi sistem tersebut. Dengan melakukan proses evaluasi terhadap sistem informasi akademik kampus, akan dapat memunculkan rekomendasi yang dapat digunakan sebagai sarana untuk meningkatkan kualitas dari sistem tersebut pada masa mendatang.

Selama ini dalam mengembangkan layanan sistem informasi berbasis web, secara umum kurang memperhatikan faktor usabilitas dari pengguna. Usabilitas didefinisikan sebagai kemampuan sistem atau perangkat untuk digunakan oleh manusia dengan mudah, efektif dan efisien serta memuaskan dengan derajat tertentu untuk mencapai tujuan yang diinginkan. 
Sedangkan menurut ISO 9241-11, usabilitas mengacu pada tingkat efektifitas, efisiensi dan kepuasan suatu produk yang telah digunakan oleh pengguna produk tersebut sehingga tujuannya dalam konteks tertentu dapat tercapai. Berkaitan dengan hal tersebut, maka metode evaluasi desain interaksi yang berkaitan dengan usabilitas membutuhkan data mentah (raw data)sebagai bahan evaluasi keterpaduan interaksi manusia dan komputer, termasuk aspek kognitif sehingga dapat ditransformasikan menjadi informasi usabilitas(Howarth, Andre, \& Hartson, 2007).

Persamaan pemodelan terstruktur atau Structural Equation Modelling (SEM) adalah suatu metode statistik yang digunakan untuk memeriksa variabel penyebab yang mempengaruhi pernyataan tertentu. Parameter dalam model SEM adalah jalur koefisien, yang berupa jalur antara variabel yang berbeda, untuk mencerminkan hubungan secara efektif. Pemilihan parameter tertentu berdasarkan analisis perbedaan yang minimal antara kovarian yang diamati dan yang tersirat oleh model struktural atau path, dengan keunggulan fleksibilitas ketika digunakan sebagai perangkat analisis dengan teori dan data(Martinez-Ruiz \& AlujaBanet, 2009).

Tujuan utama dari penggunaan SEM adalah untuk mengungkapkan pola rangkaian yang saling terkait hubungan ketergantungan secara simultan antara satu set konstruksi laten (yang tidak teramati), sehingga masing-masing diukur dengan satu atau lebih variabel manifest (yang diamati). Jadi SEM memang lebih baik untuk metode analisis kompleks.

SEM adalah teknik pemodelan yang efektif menangani multikolinieritas (jika banyak variabel yang sangat berkorelasi). Hal ini yang menjadi salah satu manfaat dari SEM yang membuatnya lebih baik dari faktor analisis dan regresi berganda dalam evaluasi usabilitas.

Dalam penelitian ini, pengukuran kualitas layanan berbasis web menggunakan instrumen ServQual(Yarimoglu, 2014). Hal ini didasarkan pada pernyataan bahwa usabilitas dan kualitas mempengaruhi satu sama lain (Seebode, 2015). Sedangkan penggunaan instrumen WebQual (Hasanov \& Khalid, 2015) bertujuan untuk mengevaluasi persepsi pengguna tentang kesesuaian situs web terhadap kebutuhan mereka. Jadi dalam studi kasus kali ini, SEM digunakan untuk menyajikan daftar variabel yang telah dimodifikasi dari variabel usabilitas, untuk mengukur usabilitas layanan web dan kualitas layanannya guna mengetahui tingkat usabilitas layanan sistem informasi akademik kampus yang berbasis web.

\section{KAJIAN PUSTAKA}

Metode ServQual merupakan instrumen untuk evaluasi dan perbaikan kualitas layanan, yang didasarkan pada analisis harapan dan persepsi pelanggan. Penggunaanmetode ServQual dan ekstensinya telah banyak digunakan untuk mengevaluasi berbagai jenis layanan di seluruh dunia.

Pada dasarnya, instrumen menggunakan kuesioner di mana individu mengevaluasi beberapa aspek layanan mempertimbangkan harapan mereka atas layanan yang akan ditawarkan dan persepsi atas layanan yang ditawarkan. Evaluasi dilakukan melalui skala Likert, yang mengukur tingkat persetujuan atau ketidaksetujuan atas simetris skala setuju / tidak setuju (Silva, Morais, \& Schramm, 2014). Jika harapan lebih besar dari hasil kinerja pelayanan, maka kualitas dirasakan kurang memuaskan dan karenanya ketidakpuasan pelanggan terjadi. Oleh karena itu, mengukur tingkat kualitas layanan, salah satu metode yang dipergunakan adalah ServQual(Jiang, Klein, Parolia, \& Li, 2012). Instrumen ServQual pada awalnya dikembangkan oleh peneliti pemasaran untuk menilai kualitas pelayanan secara umum

Model pengukuran ini menyoroti komponen utama layanan berkualitas tinggi. ServQual pada awalnya melakukan identifikasi sepuluh unsur kualitas layanan, tetapi di kemudian dilakukan proses perbaikan, sehingga berubah menjadi lima faktor, yaitu kehandalan (reliable), jaminan (assurance), tangibles, empati dan responsif (Yarimoglu, 2014)seperti yang tercantum pada tabel 1. Model ini dapat diterapkan dalam mengevaluasi layanan SI yang dikhususkan untuk memahami rekognisi dan harapan pelanggan, sehingga dapat dijadikan pertimbangan dalam meningkatkan kualitas layanan SI tersebut.

Banyak organisasi menggunakan ServQual untuk mengukur dan mengelola kualitas layanan dengan cara menyebarkan kuesioner yang mengukur baik harapan pelanggan maupun kualitas pelayanan yang mereka terima, termasuk persepsi mereka tentang layanan yang mereka terima.Dalam kaitannya dengan pengukuran sistem informasi, model pengukuran kepuasan menggunakan ServQual telah banyak dipakai peneliti, beberapa diantaranya dapat dijelaskan dibawah ini.

Penggunaan metode ServQual juga dikembangkan oleh I-Chang Tsai dan Chung-Han Yeh, dengan melakukan integrasi dengan ImportancePerformance Analysis untuk mendapatkan kualitas layanan smart campus dengan mengambil studi kasus Program Pelatihan Bahasa Inggris di Vietnam. Tujuan dari penelitian ini adalah untuk mengintegrasikan dan menerapkan solusi smart campus industri Taiwan di Dong-Nai Province of Vietnam untuk program pelatihan guru K-12 Inggris. Sebuah metode yang mengintegrasikan model kualitas layanan (ServQual) dan analisis pentingnya kinerjauntuk mengukur kualitas pelayanan berdasarkan pada kepuasan yang 
dirasakan penerima layanan dikembangkan untuk memberikan saran untuk perbaikan pelayanan kepada industri Taiwan dan untuk rendering berkualitas tinggi dan adaptif cerdas layanan kampus(Tsai \& Yeh, 2015).

Iwaarden et all. melakukan sebuah survei untuk mengidentifikasi aspek-aspek kualitas dianggap paling penting dalam desain dan penggunaan situs web. Kuesioner digunakan pada penelitian pendahuluan sebelumnya telah mengembangkan model untuk menilai kualitas situs web. Hasil yang diperoleh dari penelitian tersebut kemudian dilakukan proses perbandingan dengan dimensi Hasil penelitian menunjukkan bahwa dimensi kualitas yang ditemukan berlaku di sektor jasa juga berlaku untuk sistem informasi(Wang, Zhang, \& Ma, 2010).

James J. Jiang, et all.(2012), melakukan penelitian atas penggunaan instrumen ServQual untuk mengukur kualitas layanan Sistem Informasi, dengan melakukan uji validitas dalam populasi profesional sistem informasi. Hasil penelitian menunjukkan bahwa telah terjadi kesenjangan ekspektasi secara signifikan dan kesenjangan ini berhubungan dengan pengukuran kepuasan user(Yarimoglu, 2014).

Kiku Jones dan Lori N.K. Leonard melakukan penelitian untuk menyesuaikan konstruksi dari bisnis-to-consumer (B2C) terkait studi kepuasan ecommerce guna menentukan apakah terdapat perbedaan adalah dalam arena $\mathrm{C} 2 \mathrm{C}$ e-commerce. Konstruksi yang dibangun mencakup unsur-unsur dari model penerimaan teknologi (TAM), yang meliputi persepsi kemudahan penggunaan dan kegunaan; analisis biaya transaksi (TCA), yang mencakup ketidakpastian, aset spesifisitas, dan waktu; dan kualitas pelayanan (ServQual), yang meliputi reliability, responsiveness, assurance, dan empati. Peserta dalam penelitian ini menjawab pertanyaan tentang berbagai konstruksi dalam kaitannya dengan pengalaman mereka dengan $\mathrm{C} 2 \mathrm{C}$ e-commerce. Temuan menunjukkan bahwa TAM, TCA, dan ServQual berdampak dalam tingkat kepuasan pengguna $\mathrm{C} 2 \mathrm{C}$ e-commerce. Keandalan dan responsif (bidang kualitas pelayanan) ditemukan untuk mempengaruhi kepuasan ecommerce $\mathrm{C} 2 \mathrm{C}$, yang justru tidak ditemukan pengaruh dalam studi B2C. Temuan ini menjamin penelitian lebih lanjut dalam arena e-commerce C2C (Jones \& Leonard, 2007).

Pengukuran kualitas layanan sistem informasi sangat dibutuhkan untuk penelitian kuantitatif terkait. Sebuah studi empiris melanjutkan untuk memvalidasi suatu sistem informasi diadaptasi Model ServQual dalam konteks e-learning digunakan sistem. Data dari survei pada pengguna sistem e-learning yang digunakan untuk memvalidasi model dengan analisis faktor konfirmatori.Hasil penelitian menunjukkan bahwa sistem informasi disesuaikan Model ServQual dikenakan kebugaran yang baik dan efektivitas, dan dapat digunakan dalam penelitian masa depan yang berkaitan dengan kualitas pelayanan(Wang, Zhang, \& Ma, 2010).

TABEL 1. ASPEK EVALUASI SERVQUAL

\begin{tabular}{|c|c|}
\hline Dimensi & Definisi \\
\hline Reliabilitas & $\begin{array}{l}\text { Kemampuan untuk konsisten dalam } \\
\text { melakukan pelayanan yang dijanjikan. }\end{array}$ \\
\hline Jaminan & $\begin{array}{l}\text { Mempunyai keahlian dan pengetahuan } \\
\text { sesuai dengan kebutuhan sehingga dapat } \\
\text { memberikan pelayanan }\end{array}$ \\
\hline Bukti Fisik & $\begin{array}{l}\text { Fasilitas fisik, peralatan, dan keberadaan } \\
\text { dari personil }\end{array}$ \\
\hline Empati & $\begin{array}{c}\text { Rasa peduli dan perhatian organisasi } \\
\text { untuk pengguna }\end{array}$ \\
\hline Daya Tanggap & $\begin{array}{l}\text { Adanya keinginan membantu pengguna } \\
\text { dan memberikan pelayanan yang sesuai }\end{array}$ \\
\hline
\end{tabular}

Apabila diurutkan berdasarkan tingkat kritisnya(Parasuraman, 1994), maka aspek reliabilitas adalah aspek paling kritis secara konsisten, kemudian pada tingkat kedua adalah jaminan, tingkat ketiga oleh bukti fisik (perusahaan perbankan sangat memperhatikan aspek ini), keempat adalah oleh daya tanggap, dan kadar kepentingan yang paling rendah adalah empati.

Sedangkan WebQual merupakan metode pengukuran kualitas situs web dengan mempertimbangkan hasil rekognisi dari pengguna akhir. Metode WebQual sudah mulai dikembangkan sejak tahun 1998 dan telah mengalami pengembangan dimensi dan butir-butir pertanyaannya. Instrumen penelitian yang terdapat pada Webqual tersebut kemudian dikembangkan dengan melakukan integrasi sudut pandang customer dalam proses perancangannya. Metode ini disebut dengan istilah Quality Function Development (QFD). Pada saat ini, pengukuran menggunakan WebQual versi 4.0 berdasarkan pada tiga dimensi, yaitu :

1) Kualitas Informasi: yaitu valuasi konten yang terdapat pada situs, apakah sudah sesuai dengan kebutuhan pengguna, misalnya akurasi, format dan keterkaitannya.

2) Kualitas Layanan Interaksi: yaitu tinjauan terkait tingkat kepuasan dari interaksi layanan yang diterima pengguna layanan tersebut dengan menggunakan situs web yang lebih dalam, menurut bentuk kepercayaan dan empati, misalnya adanya jaminan keamanan dalam bertransaksi dan saling bertukar informasi, tersedianya fasilitas secara personal dan komunikasi dengan pemilik situs. 
3) Kemudahan Penggunaan: yaitu mutu yang berhubungan dengan rancangan situs, contohnya penampilan, kemudahan penggu-naan, dan navigasi oleh pengguna.

Pada versi WebQual 4.0, variabel kegunaan telah sangat berkembang, berdasarkan hasil peninjuan yang terlihat pada indikator-indikatornya yang lebih menekankan pada hasil rekognisi pengguna daripada perancang websitenya. Adapun beberapa hasil penelitian yang menggunakan WebQual dapat dijelaskan berikut ini.

Gilbert, Williams, \& Seals (2007) melakukan penelitian dengan menggabungkan tiga dimensi pada instrumen WebQual, yaitu kualitas informasi, kualitas interaksi, dan kualitas desain situs. Selanjutnya, dimensi WebQual tersebut diterapkan dalam domain lelang internet dan hasilnya digunakan untuk menilai reliabilitas instrumen untuk menilai kualitas situs web. Tiga situs lelang dievaluasi: Amazon, eBay, dan QXL melalui intervensi yang melibatkan pembelian dan penjualan di lelang. Hasil intervensi dianalisis secara kuantitatif untuk menilai validitas instrumen WebQual dan dilengkapi dengan data kualitatif yang digunakan untuk mempertimbangkan manfaat relatif dari tiga situs dievaluasi. Penggunaan WebQual 3.0 dalam penelitian didasarkan pada tiga dimensi kualitas pelanggan yang dirasakan: kualitas informasi, kualitas interaksi, dan kualitas desain situs. instrumen telah diuji dalam domain lelang online dan hasilnya menunjukkan bahwa dimensi yang digunakan, ternyata memiliki tingkat keandalan yang signifikan. Selanjutnya, dalam pengukuran usabilitas perlu melibatkan pengguna dalamjumlah memadai agar dapat memperoleh hasil pengukuran yang berkualitas (Gilbert, Williams, \& Seals, 2007).

Penelitian lain yang dilakukan Natasha Adellia dan Adhi Prasetio berfokus pada perusahaan ECommerce untuk mengembangkan web site perusahaan mereka agar sesuai dengan persepsi pelanggan karena melalui web site, terdapat interaksi langsung perusahaan dan pelanggan. Persepsi pelanggan sangat pentingkarena mempengaruhi perilaku pelanggan yang sebenarnya. Tujuan dari penelitian iniuntuk memetakan persepsi pelanggan dari e-commercepasar di Indonesia berdasarkan kesamaan masing-masingsitus pasar dan atribut kegunaan, desain situs, informasikualitas, kepercayaan dan empati sebagai kualitas inti dari WebQual 4.0.

Secara total, 385 kuesioner yang dapat digunakan diperoleh dariresponden di seluruh Indonesia melalui survei online.Multidimensional Scaling (MDS) digunakan untuk analisis data.Data dikumpulkan selama Januari hingga awal Februari 2016.Berdasarkan hasil, Tokopedia dan Bukalapak adalah e-commerce pasaryang palingideal dirasakan oleh pelanggan, sertadua perusahaan yang paling kompetitif, diikuti oleh
Elevenia,Qoo10, dan Rakuten. Hasil ini menyarankan untuk meningkatkan kualitasdari situs pasar online untuk mencocokkan persepsi pelanggan.Perusahaan harus mengevaluasi dan meningkatkan kualitassitus mereka yang terdiri dari atribut kegunaan, desain situs,kualitas informasi, kepercayaan, dan empati.(Adellia \& Prasetio, 2016).

Lee Ju Yeong, Woo Hyun Kim dan Chae RheeKim, melakukan penelitian lebih luas tentang WebQual dan ServQualPenelitian ini berfokus pada kesesuaian ponsel pintarsebagai perangkat bantu untuk perdagangan online, dan tentang dampak ponsel pintar dalam memberikan layanan pada kepuasan pelanggan. Sumber utama untuk layanan perdagangan ponsel pintar diklasifikasikan dalamtiga kategori: isi layanan, layanan jaringan nirkabeldan fitur ponsel pintar. Untuk setiap kategori, faktor layanan kritis yang terkait telah berhasil diidentifikasi. Dengan menggunakan ServQual danmodel WebQual, penelitian ini mengembangkan model yang dikembangkan untukmengukur kualitas layanan perdagangan ponsel pintar, menggunakan metode Partial Least Square (PLS)yang merupakan salah satuStructural Equation Modeling digunakan untuk menguji penelitianhipotesa. Reliabilitas dan validitas juga telah diuji. Penelitian ini menunjukkan bahwa kegunaan dan informasi dari layanan online(konten digital), aksesibilitas, keamanan dan ekonomikelayakan layanan Internet nirkabel (jaringan nirkabel)memiliki dampak yang signifikan terhadap kepuasan pelanggan. Sedangkan faktor-faktor seperti ubiquity dan kelayakan ekonomi dari karakteristik perangkat smartphone telah ditemukan tidak berpengaruh signifikan terhadap kepuasan pelanggan dalam hal perdagangan saham.(Lee, Kim, \& Kim, 2011).

\section{METODE PENELITIAN}

Berdasarkan metode pengujian tingkat usabilitas yang dikembangkan Nielsen (1994) dan mengacu pada standar ISO 9241-10, maka dalam studi kasus kali ini peneliti menggunakan variabel obyektif dan variabel subyektif yang akan diujicobakan pada mahasiswa dalam menggunakan Sistem Informasi Kampus XYZ, yang memiliki ijin untuk menyelenggarakan tiga program studi. Adapun variabel obyektif yang dipergunakan dalam penelitian ini adalah tingkat efektifitas dan tingkat efisiensi. Sedangkan daftar variabel subyektif yang digunakan adalah : tingkat kepuasan, tingkat kehandalan, komunikasi terpadu, navigasi, kemudahan kontrol, jaminan, tingkat responsif, dan kualitas informasi.

Populasi dalam penelitian ini adalah mahasiswa sebagai pengguna akhir sistem informasi akademik (SIAKAD) kampus. Proses pengumpulan data dalam penelitian dilakukan dengan cara penyebaran kuesioner secara langsung yang dilakukan 
petugas front desk, dengan menggunakan metode simple random sampling, secara proporsional untuk setiap mahasiswa dari program studi yang berbeda dengan pertimbangan mempunyai strata yang sama dan homogen. Selanjutnya petugas tersebut akan menyerahkan kuesioner kepada mahasiswa yang hadir pada saat perkuliahan pada waktu yang telah ditentukan untuk 3 (tiga) program studi. Dalam penelitian ini, jumlah kuesioner yang disebar adalah 120 buah (setiap program studi disediakan 40 kuesioner) dan yang kembali 93 buah, dengan hasil yang diperoleh dapat dilihat pada tabel 2 .

TABel 2. Hasil PERSEPsi ResPonden

\begin{tabular}{|c|c|c|c|c|}
\hline No & \multicolumn{4}{|c|}{ Keterangan } \\
\hline \multirow[t]{3}{*}{1} & \multicolumn{4}{|c|}{ Reliabilitas } \\
\hline & Kurang & Cukup & Baik & Memuaskan \\
\hline & $6.45 \%$ & $9.68 \%$ & $51.61 \%$ & $32.26 \%$ \\
\hline \multirow[t]{3}{*}{2} & \multicolumn{4}{|l|}{ Navigasi } \\
\hline & Kurang & Cukup & Baik & Memuaskan \\
\hline & $3.23 \%$ & $6.45 \%$ & $54.48 \%$ & $35.48 \%$ \\
\hline \multirow[t]{3}{*}{3} & \multicolumn{4}{|c|}{ Daya Tanggap } \\
\hline & Kurang & Cukup & Baik & Memuaskan \\
\hline & $3.23 \%$ & $3.23 \%$ & $45.16 \%$ & $48.39 \%$ \\
\hline \multirow[t]{3}{*}{4} & \multicolumn{4}{|c|}{ Keterpaduan Komunikasi } \\
\hline & Kurang & Cukup & Baik & Memuaskan \\
\hline & $1.10 \%$ & $1.10 \%$ & $42.86 \%$ & $54.95 \%$ \\
\hline \multirow[t]{3}{*}{5} & \multicolumn{4}{|c|}{ Pengendalian } \\
\hline & Kurang & Cukup & Baik & Memuaskan \\
\hline & $0 \%$ & $4.30 \%$ & $41.94 \%$ & $53.76 \%$ \\
\hline \multirow[t]{3}{*}{6} & \multicolumn{4}{|c|}{ Penjaminan } \\
\hline & Kurang & Cukup & Baik & Memuaskan \\
\hline & $2.73 \%$ & $2.73 \%$ & $58.43 \%$ & $34.83 \%$ \\
\hline \multirow[t]{3}{*}{7} & \multicolumn{4}{|c|}{ Kualitas Informasi } \\
\hline & Kurang & Cukup & Baik & Memuaskan \\
\hline & $0 \%$ & $0 \%$ & $54.84 \%$ & $45.16 \%$ \\
\hline \multirow[t]{3}{*}{8} & \multicolumn{4}{|l|}{ Efisiensi } \\
\hline & Kurang & Cukup & Baik & Memuaskan \\
\hline & $3.23 \%$ & $3.23 \%$ & $32.26 \%$ & $61.29 \%$ \\
\hline \multirow[t]{3}{*}{9} & \multicolumn{4}{|l|}{ Efektivitas } \\
\hline & Kurang & Cukup & Baik & Memuaskan \\
\hline & $3.23 \%$ & $1.08 \%$ & $35.48 \%$ & $60.22 \%$ \\
\hline \multirow[t]{3}{*}{10} & \multicolumn{4}{|l|}{ Kepuasan } \\
\hline & Kurang & Cukup & Baik & Memuaskan \\
\hline & $1.08 \%$ & $3.23 \%$ & $39.78 \%$ & $55.91 \%$ \\
\hline
\end{tabular}

Dalam penelitian ini, perancangan dan pembuatan daftar pertanyaan kuesioner melibatkan instrumen ServQual dan instrumen WebQual untuk melakukan evaluasi persepsi user tentang kualitas SIAKAD online dengan menyertakan aspek usabilitas yang telah dimodifikasi. Hal ini bertujuan untuk lebih meningkatkan aspek usabilitasnya sehingga dapat mengukur usabilitas layanan web dan kualitas layanan web. Perhitungan nilai pengaruh faktor yang terdapat pada tabel 3, diperoleh dari perhitungan bobot regresi inner dan outer yang digunakan pada persamaan pemodelan terstruktur, berdasarkan relasi Indeks Usabilitas Web 1 (IUW1) dengan Indeks Usabilitas Web 2 (IUW2).

\section{HASIL DAN PEMBAHASAN}

Untuk meningkatkan signifikansi dan pengaruh strategis kegunaan data, ada kebutuhan untuk mewakili seluruh yang membangun usabilitas sebagai variabel dependen tunggal (indeks usabilitas) tanpa mengorbankan presisi. Indeks usabilitas adalah ukuran, yang dinyatakan sebagai persentase dari seberapa dekat fitur dari pertandingan situs web yang berlaku dalam pedoman umum usabilitas. Dengan mengacu pada standar ISO 9241-10 dalam studi kasus ini digunakan agregat pertama dalam 3 variabel (sebagian besar bersifat obyektif) untuk layanan web kuantitatif dengan indeks usabilitas web site 1 (IUW1) dan untuk agregat variabel subjektif dari kegunaan : keandalan, integrasi komunikasi, navigasi, pengendalian, jaminan, daya tanggap dan kualitas informasi ke kuantitatif indeks usabilitas layanan web site 2 (IUW2 ). Tujuan dari pendekatan berbasis SEM adalah untuk mengukur hubungan struktural antara IUW1 dan IUW2.

TABEL 3. Nilai PENGARUH FAKTOR

\begin{tabular}{|l|l|c|}
\hline No & \multicolumn{1}{|c|}{ Relasi } & Nilai \\
\hline 1 & Reliabilitas $\leftrightarrow$ Navigasi & 0.18 \\
\hline 2 & Navigasi $\leftrightarrow$ Daya Tanggap & 0.23 \\
\hline 3 & IUW2 $\rightarrow$ Reliabilitas & 0.60 \\
\hline 4 & IUW2 $\rightarrow$ Keterpaduan Komunikasi & 0.58 \\
\hline 5 & IUW2 $\rightarrow$ Navigasi & 0.44 \\
\hline 6 & IUW2 $\rightarrow$ Pengendalian & 0.56 \\
\hline 7 & IUW2 $\rightarrow$ Penjaminan & 0.66 \\
\hline 8 & IUW2 $\rightarrow$ Daya Tanggap & 0.46 \\
\hline 9 & IUW2 $\rightarrow$ Kualitas Informasi & 0.63 \\
\hline 10 & IUW2 $\rightarrow$ IUW1 & 0.91 \\
\hline 11 & IUW1 $\rightarrow$ Efisiensi & 0.24 \\
\hline 12 & IUW1 $\rightarrow$ Efektivitas & 0.08 \\
\hline 13 & IUW1 $\rightarrow$ Kepuasan & 0.73 \\
\hline
\end{tabular}

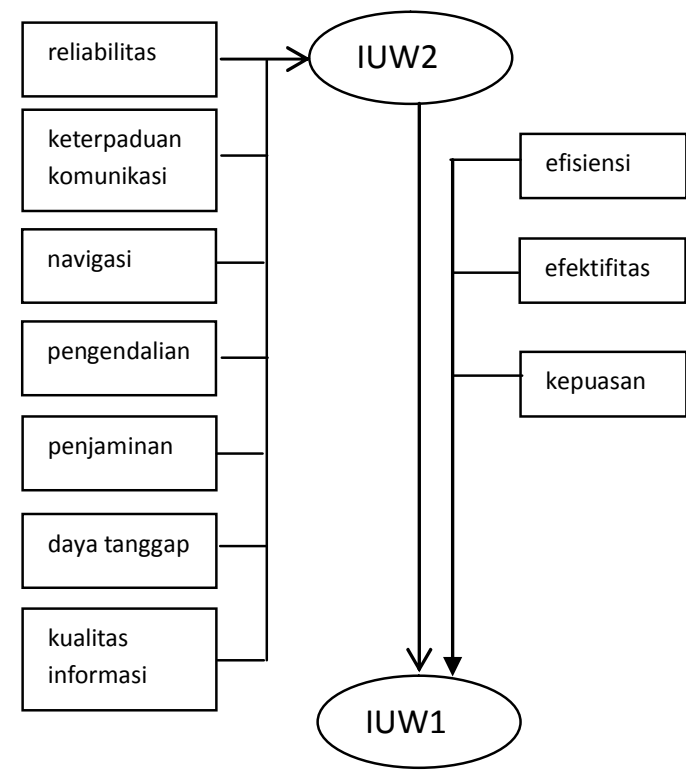

Gambar 3. Model hubungan berbagai faktor usabilitas WebQual Dengan ServQual 
Berdasarkan ketergantungan pada analisis faktor, bobot untuk masing-masing sub variabel checklist dapat ditemukan. Pengambilan nilai analisis faktor berdasarkan agregasi dari masingmasing variabel yang dapat dihitung dengan cara yang sama. Dalam pendekatan berbasis SEM ini, variabel agregat akan diasumsikan dan diamati (diukur) untuk variabel laten (unobserved) yang membangun indeks usabilitas 2 dalam hal layanan web.

Demikian pula efisiensi, efektivitas, dan kepuasan yang diamati (diukur) untuk variabel laten (unobserved) yang membangun index usability 1 dalam hal layanan web. Pendekatan ini bertujuan untuk membuktikan keabsahan dari checklist untuk evaluasi layanan web kegunaan dengan mempertimbangkan baik ukuran objektif dan subjektif dari kegunaan evaluasi dan menentukan variabel paling kritis dan usabilitas layanan web.

Model hubungan yang tampak pada Gambar 3 tersebut, secara eksperimen dipelajari dengan menguji dan mengevaluasi layanan web yang disediakan oleh sistem informasi akademik online di Politeknik XYZ. Berdasarkan pengolahan data yang dikumpulkan dan dianalisis, memperoleh hasil sebagai berikut :

- Analisis faktor eksplorasi (AFE) dengan rotasi untuk menentukan dimensi yang mendasari web layanan indeks usability 2.

- AFE dilakukan untuk menghasilkan satu set model sederhana dan dimensi non-overlapping yang berbeda dari Web Service Quality untuk Sistem Informasi Akademik Mahasiswa Politeknik XYZ. Analisis faktor menunjukkan 7 faktor yang mempunyai nilai varian sebesar $59,18 \%$ dari hasil pengamatan. Alpha Cronbach untuk faktor-faktor tersebut berkisar dari 0,69-0,75, sehingga mempunyai tingkat keandalan yang memuaskan untuk konstruksi model.

- Analisis Faktor Konfirmatori (AFK) untuk menentukan apakah dimensi diekstrak pada langkah 1 cocok baik untuk data.

- Mengukur dampak langsung dan tidak langsung dari web service usability indeks 2 di web layanan usability index 1 menggunakan pemodelan persamaan struktural.

Studi ini menemukan bobot yang berbeda untuk ukuran objektif dari kegunaan layanan web dibandingkan dengan bobot ditemukan dalam penelitian Loiacono (Lee, Kim, \& Kim, 2011) dengan hasil sebagai berikut: faktor efisiensi mempunyai pengaruh $24 \%$ menurut $25 \%$ responden, faktor efektivitas mempunyai pengaruh $8 \%$ menurut $50 \%$ responden dan faktor kepuasan mempunyai pengaruh sebesar $73 \%$ menurut $25 \%$ responden. Dalam kasus ini, para responden telah terbiasa menggunakan sistem informasi akademik yang diujikan. Jadi pentingnya efisiensi dan efektif tampaknya bisa diabaikan. Dalam studi kasus ini, kepuasan pengguna memiliki dampak terbesar pada usabilitas.

Seperti yang terlihat pada tabel 3, model tersebut menunjukkan adanya nilai-nilai dari hubungan terstruktur secara langsung antara Indeks Usabilitas Web 1 (IUW1) dan Indeks Usabilitas Web 2 (IUW2) sesuai dengan persamaan berikut : $\eta 1(\mathrm{WSUI})=\gamma 11 \xi 1(\mathrm{WSUI})+\zeta 1=0.91 \xi 1$ (WSUI2) +0.735

Model ini memiliki satu variabel endogen (variabel dependen) IUW1 dan satu variabel eksogen (variabel independen) IUW2 dengan berat regresi standar adalah 0.91 untuk hubungan antara IUW2 dan IUW1 (dengan nilai p <0,001), sehingga dapat dikatakan memberikan banyak dukungan pada hipotesis bahwa indeks usabilitas web 2 memiliki dampak langsung signifikan yang positif terhadap indeks usabilitas web 1.

Hasil penelitiansecara signifikan menunjukkan bahwa terdapat aspek obyektif dan subjektif yang mempengaruhi usabilitassistem layanan berbasis web.

\section{KESIMPULAN}

Evaluasi usabilitas dari layanan web dalam penelitian ini menggunakan kombinasi ServQual dan WebQual, yang digunakan untuk mengukur kualitas layanan yang dipadukan dengan dimensi usabilitas.

Data yang dikumpulkan dalam penelitian ini diolah untuk memperoleh indeks usabilitas kuantitatif dan indeks kuantitatif subjektif dengan menerapkan pemodelan persamaan struktural.

Hasil pengolahan menunjukkan bahwa jika dimensi kepuasan (tindakan subjektif dari indeks usabilitas) ditingkatkan, maka ukuran obyektif indeks usabilitas dapat meningkatkan secara signifikan.

Hasil penelitian ini menunjukkan bahwa aspekaspek obyektif dan subjektif yang menjadi faktor penilaian usabilitas mendapatkan hasil yang baik dan memuaskan dari hampir semua responden dalam menggunakan layanan sistem informasi akademik kampus XYZ.

\section{DAFTAR PUSTAKA}

Adellia, N., \& Prasetio, A. (2016). Customer Perception Mapping Analysis of Indonesian E-commerce Marketplace Sites based on Attributes Usability, Site Design, Information Quality, Trust, and Empathy (Case Study of Tokopedia, Bukalapak, Elevenia. 4th International Conference on Cyber and IT Service Management (hal. 1-7), Bandung, Indonesia: IEEE.

Gilbert, J., Williams, A., \& Seals, C. (2007). Clustering for Usability Participant Selection. Journal Of Usability, 3(1), 40-52.

Hasanov, J., \& Khalid, H. (2015). The Impact of Website Quality on Online Purchase Intention of Organic Food in Malaysia: A WebQual 
Model Approach. The Third Information Systems International Conference (hal. $382-$ 389 ). Serdang: Elsevier B.V.

Howarth, J., Andre, T., \& Hartson, R. (2007). A Structured Process for Transforming Usability Data into Usability Information. Journal of Usability Studies, 3(1), 7-23.

Jiang, J. J., Klein, G., Parolia, N., \& Li, Y. (2012). An Analysis of Three ServQual Variations in Measuring Information System Service Quality. Volume 15 (Issue 2).

Jones, K., \& Leonard, L. (2007). Consumer to Consumer Electronic Commerce: A distinct Research Stream. Journal of Electronic Commerce in Organizations, 5(4), 39-54.

Lee, J., Kim, W., \& Kim, C. (2011). Measuring Service Quality and Customer Satisfaction in Online Trading Services on Smart Phones. IEEE 3rd International Conference on Communication Software and Networks (ICCSN).(hal 485489). Xi'an, China: IEEE

Martinez-Ruiz, A., \& Aluja-Banet, T. (2009). Toward The Definition Of A Structural Equation Model Of Patent Value : PLS Path Modelling With Formative Constructs. Statistical Journal, 7(3), 265-290.

Parasuraman, A. Z. (1994). Reassessment of expectations as a comparison standard in measuring service quality: implications for future research. Journal of Marketing, 58(1), 111-124.
Seebode, J. (2015). Assessing the Quality and Usability of Multimodal Systems. Dalam J. Seebode, Emotional Feedback for Mobile Devices. Springer International Publishing.

Silva, V. B., Morais, D., \& Schramm, F. (2014). A Proposal of a Procedure for Evaluating Individual's Expectations and Perceptions Based on ServQual. International Conference on Systems, Man, and Cybernetics (hal. 35373541). San Diego, CA, USA: IEEE.

Tsai, I.-C., \& Yeh, C.-H. (2015). Integrating ServQual and Importance-Performance Analysis for Assessing Smart Campus Service Quality: A Case Study of an English Training Programme in Vietnam. 15th International Conference on Advanced Learning Technologies (ICALT) (hal. 436-440). Hua lien, Taiwan: IEEE.

Wang, R., Zhang, M., \& Ma, S. (2010). Validating ServQual in Information System : Empirical results from an e-learning system. 2nd International Conference on Information Science and Engineering (ICISE) (hal. 3355 3358). Hangzhou, China: IEEE.

Yarimoglu, E. K. (2014). A Review on Dimensions of Service Quality Models. Journal of Marketing Management, 2(2), 79-93. 